\title{
Evaluation of Groundwater Quality in Five Grama Divisions of Maharagama Urban Area Using Groundwater Quality Index (WQI)
}

\author{
P. A. S. A. Rathnasri and Pathmalal M. Manage \\ Department of Zoology, University of Sri Jayewardenepura, Nugegoda, Sri Lanka
}

\begin{abstract}
The Maharagama urban area is a heavily populated area in Colombo district. Groundwater in this area is having a great vulnerability for pollution by anthropogenic activities. The present study was carried out to monitor some important water quality parameters, to evaluate the quality of groundwater in the study area using a Water Quality Index (WQI) and to compare the water quality between Grama Niladari (GN) divisions in the study area. Five GN divisions (Jambugasmulla, Gangodawila south B, Wijerama, Navinna and Wattegedara) were selected for the study. 55 wells were sampled during the study. The resulted WQI values in groundwater ranged from 17.08 to 280.91 . The results revealed that the water quality of the wells deviate from excellent to very poor quality. The nitrate concentration was high $(>45 \mathrm{mg} / \mathrm{l})$ in some wells. Considering all the water quality parameters, the poorest water quality was recorded in Navinna GN division. It was observed that unregulated garbage dumping, uncontrolled application of organic and inorganic fertilizers, constructing toilet pits very close to wells and unregulated human settlements have been increasing in the study area.
\end{abstract}

KEYWORDS: Ground water, nitrate, water quality, water quality index

Corresponding author: Pathmalal M. Manage, Email: pathmalalmanage@yahoo.com 


\section{INTRODUCTION}

Water is the first need of all vital life processes. Distinctive properties such as chemical, biological and physical properties of water and its essential role in the life supporting systems are most important characters of our earth. The quantity of water easily accessible to man is considered to be $0.75 \%$ (Amarasiri, 2008). Groundwater sources are one of very important component in water cycle. The surface of the saturated zone of permeable soil is called the Water Table; water in the soil below the water table is known as groundwater (Wetzel \& likens, 2000). Since most groundwater is colorless, odorless and without specific taste it is typically most concerned with its chemical and biological qualities (Yadev et al., 2010). Ground water is a very important source of acquiring domestic water needs in Sri Lanka. Approximately 75\% of the population of Sri Lanka lives in rural environment obtaining their drinking water directly from ground (Dissanayake, 2005). Six main type of groundwater aquifers have been identified and demarcated as per studies during last 25 years. They are; Shallow Karstic Aquifer of Jaffna Peninsula, Deep Confined Aquifers, Coastal Sand Aquifers, Alluvial Aquifers, Shallow Regolith Aquifer of the Hard Rock Region, South Western Lateritic (Cabook) Aquifer (Panabokke \& Perera, 2005).

According to Harter, (2003) groundwater pollution is defined as an undesirable change in groundwater quality resulting from human activities. Considering the quality of groundwater it depends on certain factors such as the quality of recharged water, atmospheric precipitation, inland surface water and subsurface geochemical processes (Reza \& SingH, 2010). It is a clear fact that water has been considered as universal solvent hence, it has the ability to dissolve almost all natural compounds. Therefore, there is a high possibility of contamination. Once the groundwater is contaminated its quality cannot be restored by stopping the pollutants from the original source.
It therefore becomes imperative to regular monitoring of the quality of groundwater and to device ways and means to protect it (Ramakrishnaiah et al., 2008).

Natural composition of groundwater can be altered by human activities through the disposal or dissemination of chemicals and microbial matter at the land surface and into soils or through injection of wastes directly into the groundwater (Harter, 2003). Unplanned garbage disposal becomes a severe threat to groundwater quality in Sri Lanka. Currently Sri Lanka does not have a single sanitary garbage disposal ground which meets the internationally recommended standards. Thelin \& Gifford (1983) point out that open dumping sites in natural areas cause pollution of both ground and surface water. The leachate generated from the solid waste may penetrate the soil layer and pollute the water table. This can be serious especially in case where the depth of the water table is low and contaminants have short distance to travel through the ground hence they are less susceptible for microbial degradation.

Contaminants in groundwater can cause severe health problems to human especially if the water source has been used for drinking purposes. Microbial parameters are very important health parameter in drinking water. Microbes are ubiquitous in the environment around us. Therefore, microbial matter is also a natural constituent of groundwater (Harter, 2003). However, total Coliform bacteria are considered to be a health risk because they indicate possible presence of pathogenic microorganisms (Wikstrom, 1989).

The present study aims to monitor and evaluate the quality of groundwater in five selected Grama Niladhari (GN) divisions (Jambugasmulla, Gangodawila south B, Wijerama, Navinna and Wattegedara) in Maharagama urban area. The overall physicochemical condition of each well was evaluated by using a WQI. The concept of WQI was first proposed by R. K. Horton in 1965 (Yadev et al., 
2010). It indicates single number or grades that express overall water quality at certain area and time (Yadev et al., 2010). As they combine large quantity of chemical information of a water sample in to a single value WQI facilitate spatial and temporal water quality monitoring. Thereby, its application as an aggregation and communication tool can be extremely useful (Stiger et al., 2006).

\section{MATERIALS AND METHODS}

\subsection{Study Area}

The Maharagama urban area $\left(79^{0} 52^{\prime} \mathrm{E}-79^{0} 56^{\prime} \mathrm{E}\right.$ and $\left.6^{0} 50^{\prime} \mathrm{N}-6^{0} 53^{\prime} \mathrm{N}\right)$ is situated in Colombo District, Western province Sri Lanka. It is a highly urbanized area with a population density about $>1600 \mathrm{~km}^{-2}$ and has many industries and government institutes. The average annual rainfall for 2010 - 2011 is about $2670 \mathrm{~mm}$ while the mean temperature ranges between $23{ }^{\circ} \mathrm{C}$ $32.7{ }^{\circ} \mathrm{C}$ during the sampling period (Source: Dept. of Meteorology - Sri Lanka). Considering the geology the area has hornblende gneiss, hornblende - biotite gneiss and biotite gneiss. The soil type of the area is mainly red yellow podzolic soils with soft or hard laterite and bog and half bog soil. The ground water aquifer type in this area is mainly shallow regolith aquifer (Source: The National Atlas of Sri Lanka, 2007).

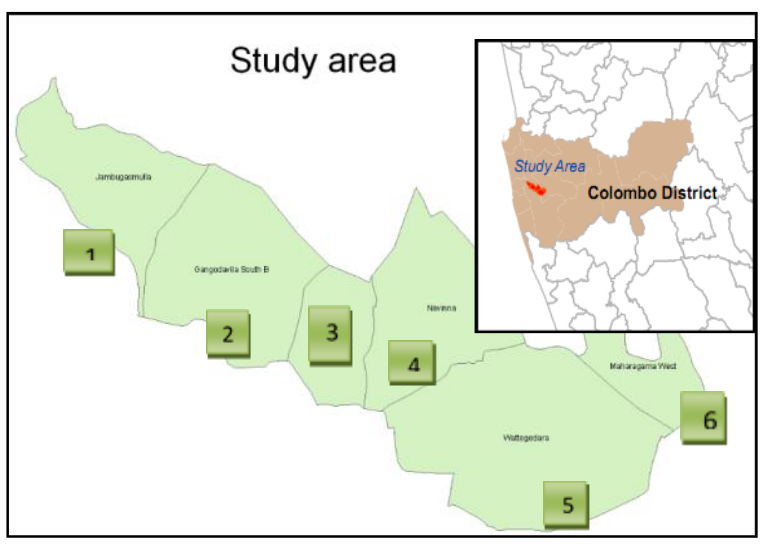

Figure 1. Map of the study area

$\begin{array}{ll}\text { 1 Jambugasmulla } & 4 \text { Navinna } \\ 2 \text { Wattegedara } & 5 \text { Gangodawila South B } \\ \text { 3 Maharagama West } & 6 \text { Wijerama }\end{array}$

Fifty five wells were selected for sampling representing the five GN divisions. Sampling was carried out during a period of nine months from November 2010 to July 2011. Samples were collected during day time three sampling occasions were performed in each well three months intervals during the study period. Number of sampling locations in each GN division is depending on the land area and availability of wells in the division (Figure 1).

\subsection{Physico-Chemical Parameters}

Fifteen Physico-chemical parameters were measured during the study period. Temperature was measured using a thermometer (model: Immersion, Philip Haris, England). $\mathrm{pH}$ and conductivity were measured using a $\mathrm{pH}$ meter (model: 340 A - set 1. WTW Co, Weilheim, Germany) and a conductivity meter (model: $340 \mathrm{i}$ - set. WTW Co, Weilheim, Germany) respectively at the site itself. Total alkalinity was measured using standard analytical method. Dissolved Oxygen (DO) (Winkler method), total hardness, chloride, nitrate and total phosphate were measured at the laboratory using standard methods (Silva et al., 1996) Heavy metals (Cd, $\mathrm{Cu}, \mathrm{Zn}, \mathrm{Fe}$ and $\mathrm{Pb}$ ) were measured using the Atomic Absorption Spectroscopy (AAS). Water samples (except the samples for $\mathrm{Fe}$ analysis) were preserved with conc. HNO3 to $\mathrm{pH}<1$ before heavy metal analysis

Twelve physico- chemical parameters were used to calculate the WQI including total alkalinity, hardness, conductivity, $\mathrm{pH}$, chloride, nitrate, total phosphate and five heavy metals $(\mathrm{Cd}, \mathrm{Cu}$, $\mathrm{Zn}, \mathrm{Fe}$ and $\mathrm{Pb}$ ).

First, a weight value was assigned for each of the twelve parameters depending on their relative importance. The maximum weight (5) has been assigned to parameters with major importance.

Then, the relative weight was calculated using the following equation. 


$$
W i=w i / \sum_{i=1}^{n} w i
$$

Where $W_{i}$ is the relative weight of $i^{\text {th }}$ parameter, $\mathrm{W}_{\mathrm{i}}$ is the assigned weight of the $\mathrm{i}^{\text {th }}$ parameter

Table 1. Assigned $\mathrm{w}_{\mathrm{i}}$ and calculated $\mathrm{W}_{\mathrm{i}}$ values for each parameter and $\mathrm{n}$ is the number of parameters. Table 2 demonstrates the assigned $\mathrm{W}_{\mathrm{i}}$ values and calculated $\mathrm{W}_{\mathrm{i}}$ values.

\begin{tabular}{|c|c|c|}
\hline Parameter & Weight $\left(\mathbf{w}_{\mathbf{i}}\right)$ & $\begin{array}{c}\text { Relative } \\
\text { weight }\left(\mathbf{W}_{\mathbf{i}}\right)\end{array}$ \\
\hline $\mathrm{pH}$ & 4 & 0.08696 \\
\hline Hardness & 2 & 0.04348 \\
\hline Total alkalinity & 3 & 0.06521 \\
\hline Chloride & 3 & 0.06521 \\
\hline Conductivity & 2 & 0.04348 \\
\hline Nitrate & 5 & 0.10870 \\
\hline Total phosphate & 4 & 0.08696 \\
\hline Iron & 4 & 0.08696 \\
\hline Zinc & 4 & 0.08696 \\
\hline Copper & 5 & 0.10870 \\
\hline Lead & 5 & 0.10870 \\
\hline Cadmium & 5 & 0.10870 \\
\hline & $\sum \mathrm{W}_{\mathrm{i}}=46$ & $\sum \mathrm{W}_{\mathrm{i}}=1$ \\
\hline
\end{tabular}

Table 2. Water quality classification based on WQI value

\begin{tabular}{|c|c|}
\hline WQI value & Water quality \\
\hline$<50$ & Excellent \\
\hline $50-100$ & Good water \\
\hline $100-200$ & Poor water \\
\hline $200-300$ & Very poor water \\
\hline$>300$ & Water unsuitable for drinking \\
\hline
\end{tabular}

In the third step a quality rating scale for each parameter was assigned using the following equation.

$$
q i=100 C i / S i
$$

Where $\mathrm{q}_{\mathrm{i}}$ is the quality rating, $\mathrm{C}_{\mathrm{i}}$ is the concentration of each chemical parameter in each water sample and $\mathrm{S}_{\mathrm{i}}$ is the Sri Lankan drinking water standard for each chemical parameter. To calculate the WQI the SI value for each parameter was computed using the following equation.

$$
S I i=W i / q i
$$

Where $\mathrm{SI}_{\mathrm{i}}$ is the sub index of $\mathrm{i}^{\text {th }}$ parameter and $W_{i}$ is the relative weight of $i^{\text {th }}$ parameter. Then the WQI was determined by following equation.

$$
W Q I=\sum_{i=1}^{n} S I
$$

Where $\mathrm{n}$ is the number of chemical parameters measured in each well water sample. The computed WQI values were classified into five types from excellent water to water unsuitable for drinking. Table 3 illustrates the quality rating scale of the WQI values (RAMAKRISHNAIAH et al., 2009: REZA \& SINGH, 2010; YADEV et al., 2010).

\subsection{Microbiological Parameters}

Total Coliform and fecal Coliform count per 100 $\mathrm{ml}$ of water was determined by multiple tube fermentation method (Silva et al., 1996).

The production of gas bubbles in durham tubes indicates the possibility of presence of Coliform and $E$. coli bacteria. The bacterial count of both tests was taken from a standard MPN table (Benson, 1998).

\section{RESULTS AND DISCUSSION}

\subsection{Water Quality of the Study Area with Reference to the WQI}
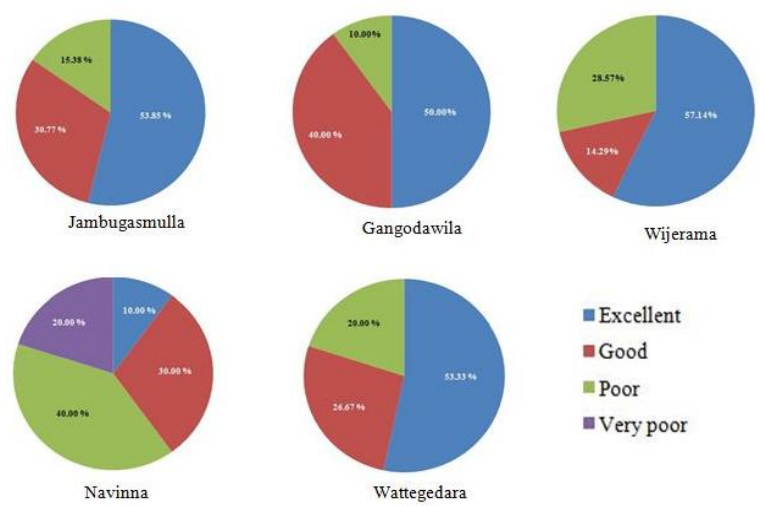

Figure 2. Percentage of the well water quality in Jambugasmulla, Gangodawila, Wijerama, Navinna and Wattegedara GN divisions 
According to calculated water quality index the overall quality of the ground water in the study area ranges from excellent to very poor quality. The worst quality is reported from Navinna GN division (Figure 2).

Considering the entire study area, the overall WQI ranged from 17.08 to 280.91 means that the water quality in the study area varies from excellent quality to very poor quality. Navinna has the most deteriorated water quality. It can be suggested that the most possible cause for the deterioration of groundwater quality in Navinna GN division is the huge garbage dumping site located in the middle of the city. As it is uncovered and unprotected the generated leachate may penetrates through the ground and contaminates the groundwater table.

A previous study done by Welgamage in 2007 recorded similar results. However, the study was mainly focused on close proximities of the dumping site and therefore considered the direct impact from the dumping site onto groundwater table. According to opinions of people in the area there are other pollution sources such as factories and industries. Similar study was done in Tamil Nadu; South India by Usharani et al, 2010 also suggested that the garbage dumping can be a main reason for the poor groundwater quality in their study area.

\subsection{Nitrate Concentration of the Groundwater}

Out of all the measured physico-chemical parameters nitrate has been especially considered in this study, because some wells throughout the study area show a very high concentration of nitrate. Although the recommended standard for nitrate is $45 \mathrm{mgl}^{-1}$ most of the wells show nitrate concentration higher than the recommended standards.

More than $20 \%$ of the wells in every GN division contain high nitrate levels ( $>45 \mathrm{mgl}-1)$ which are unsuitable for human consumption. The highest percentages $(53.34 \%)$ of wells which contains nitrate concentration greater than 45mgl-1 can be seen in Wattegedara GN division. Unfortunatly, even a single well cannot be seen in Wattegedara that has nitrate concentration less than $15 \mathrm{mgl}^{-1}$ all the time during the study period greater nitrate levels in the well water was detected.

\subsection{Microbiological Parameters}

The Sri Lankan standard for total Coliform in drinking water is $10 / 100 \mathrm{ml}$ and for fecal Coliform is $0 / 100 \mathrm{ml}$. However, almost all the wells in the study area were reported as contaminated with total Coliform and fecal Coliform during the study. Most of the wells contain very high total Coliform and fecal Coliform count. In Wijerama and Navinna 100\% of the monitored wells are contaminated and therefore, unsafe for direct human consumption. In other divisions more than $80 \%$ of wells are unsafe for direct consumption.

The results obtained in the research are tally with the previous study done by Welgamage, in 2007. The results obtained from the previous study clearly demonstrated that wells within $150 \mathrm{~m}$ from the Navinna dumping site have been contaminated with Coliform bacteria. Therefore, it can be said that dumping of municipal wastes and other household wastes including sewage can result microbial contamination in ground water. However, the results obtained from the present study further suggested that the contamination does not limit to the associated areas of the garbage dumping site but can be seen in other areas as well.

\section{ACKNOWLEDGMENT}

The study was financially supported by the University of Sri Jayewardenepura.

\section{REFERENCES}

AMARASIRI S. Caring for water. Sri Lanka Nature forum, Nugegoda. 2008. 
BENSON HJ. Microbial Application: Laboratory manual in General Microbiology (7th ed.). Boston: Mc-Grow hill. 1998.

DISSANAYAKE CB. Water Quality in the Dry Zone of Sri Lanka- Some interesting health aspects. Journal of National Science Foundation Sri Lanka. 33(3): 161-168.

HARTER T. Groundwater quality and Groundwater pollution. Division of Agriculture and Natural Resources University of California. Retrieved $25^{\text {th }} \quad$ May 2011 from http://groundwater.ucdavis.edu/Publications/Har ter_FWQFS_8084.pdf. 2003.

PANABOKKE CR \& PERERA APGRL. Ground Water Resources of Sri Lanka. Water Resources Board. Colombo 07. 2005.

RAMAKRISHNAIAH CR, SADASHIVAIAH C \& RANGANNA G. Assessment of water quality index for the groundwater in Tumkur Taluk, Karnataka state, India. E- journal of Chemistry. 2008; 6(2): 523 - 530. Retrieved May $25^{\text {th }} \quad 2011$ from, http://www.e.journals.in/PDF/V6N2/523-

530.pdf.

REZA R \& SINGH G. Assessment of Groundwater quality status by using a Water Quality Index method in Orissa, India. World applied Science Journal. 2010; 9(12): 1392 1397. Retrieved May $25^{\text {th }}$ May 2011, from, http://www.idosi.org/wasj/wasj9\%2812\%2910/1 1.pdf.

SILVA EIL, NAMARATHNE SY, WEERASOORIYA SVR \& MANUWEERA L. Water Analysis- User friendly field/ laboratory manual. Institute of fundamental studies: Sri Lanka.1996.

STIGER TY, RIBEIRO L \& CARVALHODILL AMM.. Application of groundwater quality index as an assessment and communication tool in agro- environmental policies; two Portuguese case studies. Journal of Hydrology. 2006; (327): 578 - 591.

Survey department of Sri Lanka. The National Atlas of Sri Lanka. 2007.

USHARANI K, UMARANI K, AYYASAMY PM, SHANTHI K, \& LAKSHMANAPERUMALSAMY P. Physicochemical and Biological Characteristics of Noyyal River and Groundwater Quality of Perur, India. Journal of Applied Sciences \& Environmental management. 2010; 14(2): 29-35.

WELGAMAGE DACD. A Microbiological study of some well water quality parameters with reference to the garbage dumping site at Navinna Area (B.Sc. dissertation, University of Sri Jayewardenepura, Sri Lanka).2007.

WETZEL GR \& LIKENS GE. Limnological Analysis ( $3^{\text {rd }}$ ed.). New York: Springer Verlag.2000.

YADEV AK, KHAN P \& SHARMA SK. Water quality index assessment of Groundwater in Todarasingh Tehsil of Rajasthan State, India - A Greener approach. E- journal of Chemistry, 2010; 7(S1):428 - 432. Retrieved 25 $5^{\text {th }}$ May 2011 from,http://www.ejournals.in/PDF/V7NS1/S428 -S432.pdf. 